International Research Journal of Management, IT \& Social Sciences
Available online at https://sloap.org/journals/index.php/irjmis/
Vol. 7 No. 3, May 2020, pages: 126-136
ISSN: 2395-7492
https://doi.org/10.21744/irjmis.v7n3.931

\title{
The Effect of Auditor Rotation, Time Pressure, and Audit Tenure on Audit Quality with Auditor Specialization as Moderation Variable (Empirical Study of Manufacturing Companies Listed on the Indonesia Stock Exchange in 2014-2018)
}

\author{
I Gusti Ayu Monika Intan Kirana
}

I Wayan Ramantha ${ }^{b}$

\section{Article history:}

Submitted: 27 March 2020

Revised: 09 April 2020

Accepted: 18 May 2020

\section{Keywords:}

audit quality;

audit tenure;

auditor rotation;

auditor specialization;

time pressure;

\begin{abstract}
The purpose of this study was to determine and obtain empirical evidence about the effect of auditor rotation, time pressure, and audit tenure on audit quality with auditor specialization as a moderating variable. This research was conducted at manufacturing companies listed on the Indonesia Stock Exchange in 2014-2018. The number of samples is 81 companies with the number of observations as many as 405 samples in 5 years, through the nonprobability method with a purposive sampling technique. This research analysis technique uses Moderate Regression Analysis (MRA). Based on the results of the analysis found that audit rotation does not affect audit quality. Time pressure influences audit quality. Audit tenure affects audit quality. The auditor's specialization does not affect audit quality.
\end{abstract}

International research journal of management, IT and social sciences ()$^{2} 2020$. This is an open access article under the CC BY-NC-ND license (https://creativecommons.org/licenses/by-nc-nd/4.0/).

Corresponding author:

I Gusti Ayu Monika Intan Kirana,

Faculty of Economics and Business, Udayana University (Unud), Denpasar, Indonesia.

Email address: monika.kirana@gmail.com

Faculty of Economics and Business, Udayana University (Unud), Denpasar, Indonesia

Faculty of Economics and Business, Udayana University (Unud), Denpasar, Indonesia 


\section{Introduction}

Management in a company, especially those relating to management in the financial sector, is important for the continuity of the operation of the company. The company needs to prepare the financial statements as well as possible so that there will be no difference between management and shareholders and the most important is being able to meet the rules that have been set both in accounting and government (Ardani, 2017).

In the theory proposed by De Angelo in 1981, it defined audit quality is the probability that the auditor will find and report violations in the client's accounting system. Whereas the probability of finding a violation depends on the auditor's technical ability, and the probability of reporting a violation depends on the auditor's independence (Law et al., 2012; Kesuma \& Dwirandra, 2019; Lowensohn et al., 2007; Lennox, 2005). The results of the audit process are expected to reduce fraud in the preparation of financial statements, especially in public companies that are of concern to the parties concerned. As it is well known that there were also frauds committed by large companies in preparing their financial statements. An example is the disclosure of the Enron Corporation case in 2001 in the United States, followed by other large companies such as Tyco International, Adelphia Communication, Global Crossing, Xerox Corp., the Walt Disney Company, and the ImClone System Incorporation which also committed fraud in preparing company's financial statement (Deil, 2014; Crabtree et al., 2006; Gul et al., 2009).

A similar condition has also occurred in Indonesia, namely the case audit failures as happened to Kimia Farma and Lippo Bank. The audit failure that occurred in Kimia Farma's case was the mark up of the company's profit wherein 2001 it was written Rp 132 billion when in fact it was only valued at Rp 99,594 billion. Meanwhile, the case that occurred at Lippo Bank was a double accounting in 2002. In that year Bapepam found three different versions of financial statements for the public, the Jakarta Stock Exchange and financial reports submitted by public accountants namely Prasetio Public Accountant Office, Sarwokodan Sandjaja with auditor Ruchjat Kosasih (Suryo, 2017).

Another problem that concerns the quality of corporate audits in Indonesia is what has happened lately with the disclosure of cases that have befallen PT. Sunprima Nusantara Financing (SNP Finance). This case is related to complaints in violations of the 2012-2016 financial statement audit process by several Public Accounting Firms including Marlinna Public Accountants, Merliyana Syamsul Public Accountants, and Public Accountants Satrio Bing, Eny \& Partners (Delloitte Indonesia). In the process, it was found that there were treatments from public accountants who had not fully implemented and complied with the Standard of Public Accountants and standard Professional Audit in conducting a general audit of financial statements in PT. SNP Finance.

There are also cases of PT. Asuransi Jiwasraya, which is currently facing a problem. The oldest life insurance company in Indonesia is forced to postpone payment of policy obligations that are due. Delays in payments made for 711 bancassurance products worth Rp 802 billion. The case of failure to pay a customer policy that leads to corruption in PT Asuransi Jiwasraya that considered to involve many parties including public accountants. The auditor is deemed incapable or reveals his true condition to Jiwasraya. What's more, the audited financial statements published by Jiwasraya turned out to have been manipulated or window dressing so the company looked good.

Research on auditor rotation, time pressure, audit tenure, audit quality, and auditor specialization has been examined by several previous researchers. Chi et al. (2009), state that the length of the relationship that occurs between the auditor and the company as a client is expected to be able to influence the auditor's independence in conducting the audit process because of the objectivity in the audit is decreased. From this situation, the auditor rotation policy is expected to be able to maintain independence from the auditor in conducting the audit process so it will produce a good audit quality (Elder et al., 2015). While in other studies by Andriani \& Nursiam (2018); Nizar (2017); Ardani (2017); and Maharani (2014) concluded that auditor rotation did not have a significant effect on audit quality results.

The other factors that can affect audit quality are time pressure and audit tenure. It is stated that time pressure is an environmental feature that is commonly faced by auditors. The deadline for completing an audit makes the auditor have a busy period that demands he work quickly. The time budget is a very important benchmark for all Public Accounting Firms (KAP) from the time provided can be used as a basis for estimating audit costs, allocating staff into audit work, and as a basis for evaluating auditor performance (Basuki \& Krisna, 2006). On the other hand, there is time pressure in the audit process because a faster deadline will make the auditor tend to evaluate efficiently so that it is possible to reduce the quality of the audit process carried out. Especially if the application of these evaluation methods is not sanctioned by the accounting firm, the tendency to reduce audit quality becomes worse (Sweeney \& Pierce, 2004).

Besides the two factors that have been mentioned, there are still other factors that will affect the quality of the audit results, another factor is audit tenure. It was stated that audit tenure can influence the quality of the audit results. Audit tenure is defined as the length of time required by the auditor in carrying out the audit process. The results of the study

Kirana, I. G. A. M. I., \& Ramantha, I. W. (2020). The effect of auditor rotation, time pressure, and audit tenure on audit quality with auditor specialization as moderation variable. International Research Journal of Management, IT and Social Sciences, 7(3), 126-136. https://doi.org/10.21744/irjmis.v7n3.931 
concluded that the longer the auditor's time in conducting an audit the worse the quality of the audit (Djamil, 2003). While the results of research by Ardani (2017), mentioned that audit tenure provides a positive relationship to audit quality. This is also consistent with research submitted by Nugrahanti \& Darsono (2014) that a short audit period results in the acquisition of limited information, data, and evidence. If an audit contains erroneous data or data that managers accidentally omitted, it will be more difficult to find. On the other hand, a long audit work period can help the auditor to develop greater awareness of the company's conditions that facilitate the inspection process and make it easier to detect and report errors that occur in the audit report. In addition to the significant influence exerted by audit tenure on audit quality, there are also results of studies that state that audit tenure does not have a significant effect on audit quality (Rahmina \& Agoes, 2014).

Based on the results of the other studies it was revealed that the auditor's specialization factor was able to provide an effect that was able to strengthen the influence of the audit quality factors. This can be seen in research conducted by Kurniati (2018) which concluded that auditor specialization can strengthen the relationship between auditor reputation and rotation on audit quality.

According to the results found in several previous studies, it was concluded that there are factors that influence and do not influence the results of the audit process to the company's financial statements. So based on this, the researcher will review the factors that have been collected into one that is estimated to be able to influence the results of the audit quality that occurred on the list of manufacturing companies on the Indonesia Stock Exchange for the period 2014 2018.

\section{Literature review}

\section{Audit Quality}

De Angelo's theory in 1981 explained that audit quality as a possibility where the auditor will find and report material misstatements in a company's financial statements. Rosnidah et al. (2011), in their research found that audit quality is the conduct of audits conducted that according to standards so that they can disclose and report fraud by clients. In this case, the audit has a function as a process to reduce the misalignment of information that exists between managers and shareholders by using outsiders to provide endorsement of the financial statements

2. Auditor's Rotation

Auditor's Rotation according to Sumarwoto (2006) is as follows: "In general, auditor rotation has two characteristics, namely mandatory, and voluntary. Auditor Rotation is replacing auditor that occurs due to mandatory regulations and can occur voluntarily which is optional (voluntary) from the auditor and based on management decisions (Davidson et al, 2005).

3. Time pressure

According to Nirmala \& Latrini (2017), Time budget pressure is a condition that shows that auditors are required to make efficiency in the time budget that has been prepared or there is a very tight and rigid budget time discussion. The Time Budget Pressure given by KAP to its auditor aims to reduce audit costs. The faster the time for conducting the audit, the smaller the cost of conducting the audit (Lestari \& Nedya, 2019). The existence of time pressure can affect audit quality, where it is based on the assumption that related to the audit pressure experienced by the company during the acceleration period, the presence of time pressure will cause difficulties in the audit process, so many companies are trying to ease the audit time pressure so that audit quality generated can be accelerated and can still provide accurate information to users of financial statements (Lambert et al., 2017).

4. Tenure Audit

Tenure Audit is the length of the auditor and client relationship as measured by the number of years (Junaidi et al., 2016). Tenure is the audit engagement period between KAP and client-related to audit services that have been agreed in advance or can also be interpreted as the period of the relationship between the auditor and the client (Sinaga \& Ghozali, 2012). Tenure becomes a debate during the tenure audit period that is briefly carried out and the tenure audit period that is conducted for a long period. Hamid (2013), argues that with a short tenure period when the auditor gets a new client, it requires additional time for the auditor to understand the client and the business environment.

5. Audit Specialization

Rahadianto (2012), defines that the auditor industry specialization as a specific understanding and ability in a particular industry gained from the auditors' experience in auditing and special training on audits of a particular industry to improve audit quality. While Herusetya (2009) states that the industry specialization possessed by 
auditors provides more knowledge to detect errors so as to be able to improve the efficiency and correctness of financial statements.

\section{Research hypothesis}

Regulations issued by the government through PP No. 20 of 2015 concerning the Practice of Public Accountants which requires companies to periodically carry out auditor rotations for a maximum of 5 consecutive financial years. Auditor rotation policy allegedly will have a significant impact on the strength of the independence of an auditor on the audit process that will be done. Results of research by Perdana in Nizar (2017). Also, according to Church \& Zhang (2006); Firth et al. (2012); Wang \& Tuttle (2009), rotation in the audit will provide benefits to the company in producing good audit quality depending on several things, one of which is audit fees. However, auditor rotation conducted in a fast period will hurt audit quality, as the results of research by Gietzmann \& Sen (2002).

$H_{1}$ : Auditor rotation affects audit quality

Doing audit work for hours to meet deadlines can increase auditor vulnerability so that it will have an impact on audit quality (Bhaskar et al., 2017). Meanwhile, in another explanation, it was stated that the occurrence of audit time budget pressure would result in the public accountant accelerating the completion of steps in the audit program so that it would reduce the amount of work that should have been carried out following the planned audit program (Arrens et al., 2012). $\mathrm{H}_{2}$ : Time pressure affects audit quality

Tenure Audit is the period the auditor's engagement with the client is measured by the number of years. Audit Tenure is concerned with being aware of the auditor's familiarity with clients. It is feared that the relationship between the auditor and the client for a long period will lead to the loss of auditor independence. Research conducted by Lee \& Sukartha (2017); Pieters \& Warlop (1999), obtained evidence that audit tenure has a positive effect on audit quality. The same thing also happened in research conducted by Indriani \& Kusumaputra (2017) which proved that audit tenure affects audit quality. While research conducted by Yahya (2015) proves that audit tenure does not affect audit quality. $H_{3}$ : Tenur Audit affects audit quality

Specialist auditors are more likely to detect errors and deviations from non-specialist auditors. According to Ishak et al. (2015), auditors who have better knowledge and understanding of internal control company, company business risk, and audit risk in the industry. Specialization of auditors in certain industries makes these auditors possess adequate ability and knowledge compared to auditors who do not specialized. Through specialization in the audit process, the auditor will be able to sort out what is needed in the audit process so that it will simplify the audit process following the characteristics of the company being audited.

$\mathrm{H}_{4}$ : Audit specialization affects audit quality

Gietzmann \& Sen (2002), conclude that auditor rotation in a short period will give negative results on audit quality because the auditor does not fully understand the grid of the new client he is handling. While Church \& Zhang (2006), states that rotations in auditing will benefit companies in producing good audit quality depending on several things, one of which is audit fees. About audit fees, the auditor quality aspect is something that cannot be ruled out. Specialization of auditors in this regard will be given more costs because it is expected to be able to provide appropriate audit quality results.

$H_{5}$ : Auditor specialization strengthens the effect of auditor rotation on audit quality

The results of research conducted by Bhaskar et al. (2017), that complexity in conducting audits aimed at meeting the deadlines will make auditors take steps as efficiently as possible, so that there may be deficiencies in the audit process. Audit specialization is the expertise and experience of an auditor in certain industrial fields (Luhgiatno in Kurniawansyah, 2017). Auditors who have experience in certain industries will be able to detect errors in client data so that it can reduce the management practices even though the circumstances that occur, auditors get a large deadline (time pressure) to be able to complete the audit process following the deadline (Pieters \& Warlop, 1999). In this condition, it is expected that the greater time pressure and auditor specialization is expected to strengthen the relationship of time pressure to audit quality so that the resulting audit quality meets the standard of actual accounting principles (Lowensohn et al., 2007).

$H_{6}$ : Auditor specialization strengthens the effect of time pressure on audit quality

Kirana, I. G. A. M. I., \& Ramantha, I. W. (2020). The effect of auditor rotation, time pressure, and audit tenure on audit quality with auditor specialization as moderation variable. International Research Journal of Management, IT and Social Sciences, 7(3), 126-136. https://doi.org/10.21744/irjmis.v7n3.931 
Arie in Nuratama (2011), said that the length of time. Audit assignments can improve audit quality for various reasons. First, high audit costs (including audit failures) is associated with the initial audit assignment period with the assumption although the auditor's independence level is relatively higher at the beginning of the assignment period, the level of familiarity is lower, it has been seen from the high level of audit failures in the initial period. The second argument from the positive side of the duration of audit assignments says that knowledge about the industry obtained increases after repeated audits, thereby increasing audit quality. Senjaya \& Suprasto (2016) explain that the level of specialization of the auditor industry is the auditor's understanding and specific ability to a particular industry gained from the auditor's experience in auditing and special training on audits of a particular industry to improve audit quality $H_{7}$ : Auditor specialization strengthens the effect of audit tenure on audit quality

According to the introduction and literature review, this is the conceptual framework for this research:

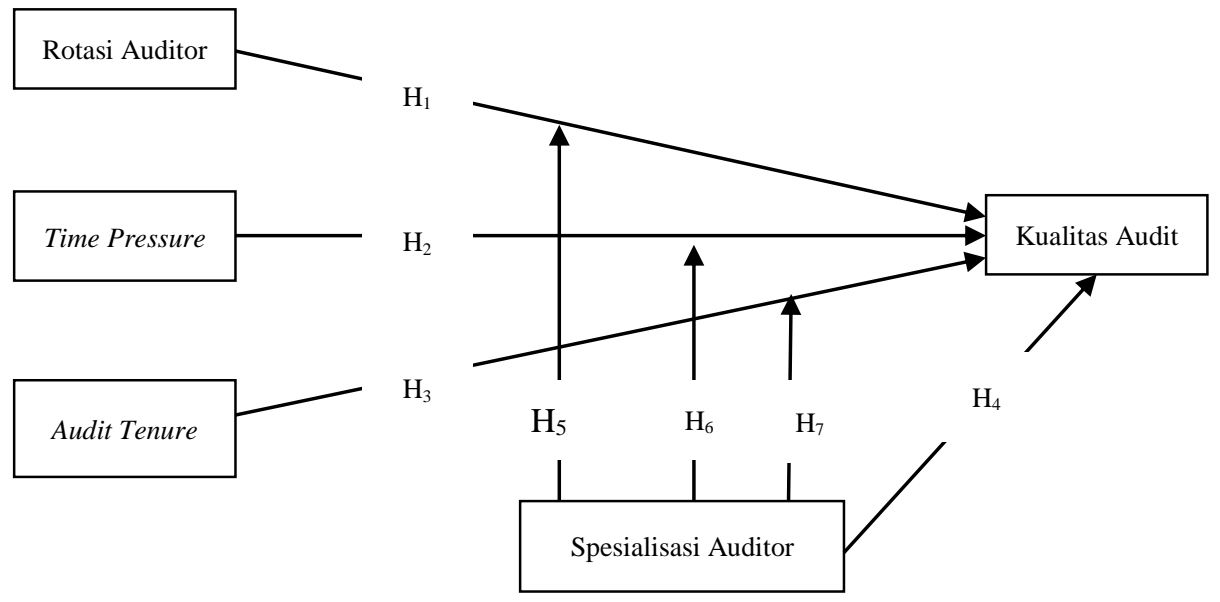

\section{Materials and Methods}

This research was conducted at manufacturing companies listed on the Indonesia Stock Exchange through its official website, www.idx.co.id OK stock website www.sahamok.com. The object of this research is auditor rotation, time pressure, audit tenure, auditor specialization, and audit quality in manufacturing companies listed on the Indonesia Stock Exchange (IDX) in the period 2014-2018.

The population used in this study is manufacturing companies listed on the Indonesia Stock Exchange in 2014 to 2018 using a purposive sampling method with the following criteria:

1) Manufacturing companies on the IDX registered respectively from 2014-2018.

2) Manufacturing companies that do not conduct mergers and acquisitions.

3) Financial statements of manufacturing companies using the rupiah and close books on December 31 each year. The data analysis technique used in this study is Moderated Regression Analysis (MRA).

\section{Results and Discussions}

Descriptive statistics provide information on the characteristics of the research variables, especially related to the minimum value, maximum value, mean value, and standard deviation. The results of the descriptive statistical analysis of the study can be seen in Table 1 . 
Table 1

The results of the descriptive statistical analysis

\begin{tabular}{llllll}
\hline & N & Minimum & Maximum & Mean & $\begin{array}{l}\text { Std. } \\
\text { Deviation }\end{array}$ \\
\hline Rotasi Auditor & 405 & 0 & 1 & .12 & .321 \\
Time Pressure & 405 & 22 & 349 & 79.59 & 20.125 \\
Audit Tenure & 405 & 1 & 5 & 2.53 & 1.396 \\
Spesialisasi Auditor & 405 & 0 & 1 & .35 & .478 \\
Kualitas Audit & 405 & 0 & 1 & .43 & .495 \\
Valid N (listwise) & 405 & & & & \\
\hline
\end{tabular}

Source: processed data, 2019

Based on the descriptive statistical test results of Table 1 above, the auditor rotation variable uses a dummy scale where the company that rotates the auditor is given a score of 1 , and the company that does not rotate the auditor is given a score of 0 . The mean of auditor rotation is 0.12 . The average value of auditor rotation is closer to the minimum value, this means that the average company tends not to rotate the auditor.

The Time pressure variable in the study is associated with the length of the audit process that exceeds the deadline for delivery (audit delay) to the Financial Services Authority. The time pressure variable has a minimum value of 22 which means the lowest value of the time pressure variable is 22 days. The maximum value of time pressure is 349 , which means the highest value of time pressure variable is 349 days. The mean time pressure of 79.59 means that the average time pressure of the sample company is 79.59 days. The standard deviation value of 20.125 is smaller than the mean which means there is a low fluctuation of the time pressure variable in the company that is being sampled.

The audit tenure variable has a minimum value of 1 , which means the lowest value of the auditor's engagement with the client for 1 year. The maximum value of audit tenure is 5, which means the highest value of the period of the auditor's engagement with Kline is 5 years. The mean value of the audit tenure variable is 2.53 , which means the average length of the auditor's engagement with the client is 2.53 years. The standard deviation of 1.396 is smaller than the mean, which means there is a low fluctuation of the audit tenure variable in the sample company.

The auditor specialization variable is determined based on if the relevant firm KAP controls $>10 \%$ market share in an industry, then it is given a value of 1 . While if mastering $10 \%$ and below, then given a value of 0 . The mean of the auditor specialization is equal to 0.35 . The standard deviation of the auditor specialization variable is 0.478 greater than the mean, which means that there is a high enough fluctuation than the auditor specialization variable.

The audit quality variable in this study uses a dummy scale with the provision of a score of 1 if the auditor used by the company is a KAP of the big four groups, and a score of 0 if the company's auditor uses the services of the KAP of the nonbig four groups. The mean of the audit quality variable is 0.43 . The standard deviation value of the audit quality variable is 0.495 greater than the mean which means that there are quite high fluctuations from the audit quality variable.

The data were tested using a moderation regression analysis technique. The results are presented in Table 2.

Table 2

Moderation regression analysis results

Coefficients $^{\mathrm{a}}$

\begin{tabular}{llllll}
\hline Model & \multicolumn{2}{l}{$\begin{array}{l}\text { Unstandardized } \\
\text { Coefficients }\end{array}$} & $\begin{array}{l}\text { Standardized } \\
\text { Coefficients } \\
\text { Beta }\end{array}$ & $\mathrm{t}$ & Sig. \\
& $\mathrm{B}$ & Std. Error & Beta & & \\
\hline 1 (Constant) & .260 & .105 & & 2.475 & .014 \\
Rotasi Audit & -.035 & .079 & -.023 & -.445 & .656 \\
Time Pressure & -.002 & .001 & -.089 & -2.036 & .042 \\
Audit Tenure & .066 & .021 & .186 & 3.196 & .002
\end{tabular}

Kirana, I. G. A. M. I., \& Ramantha, I. W. (2020). The effect of auditor rotation, time pressure, and audit tenure on audit quality with auditor specialization as moderation variable. International Research Journal of Management, IT and Social Sciences, 7(3), 126-136. https://doi.org/10.21744/irjmis.v7n3.931 


\begin{tabular}{llllll}
\hline \multicolumn{1}{l}{ Spesialisasi } & .518 & .375 & .499 & 1.380 & .168 \\
$\quad$ Auditor & & & & & \\
Interaksi X. $\mathrm{Z}$ & -.270 & .198 & -.066 & -1.365 & .173 \\
Interaksi $\mathrm{X}_{2} . \mathrm{Z}$ & .003 & .005 & .203 & .565 & .572 \\
$\quad$ Interaksi X. $\mathrm{Z}$ & -.075 & .033 & -.237 & -2.257 & .025 \\
R Square: & & 0,307 & & & \\
Adjusted R Square: & & 0,295 & & & \\
F Statistik: & & 25,146 & & & \\
Signifikansi: & & 0,000 & & & \\
\hline
\end{tabular}

Source: processed data, 2019

The coefficient of determination $\left(\mathrm{R}^{2}\right)$ of 0.307 means that the ability of the model to explain variations in the dependent variable is 30.7 percent. Adjusted $\mathrm{R}^{2}$ value of 0.295 indicates that 29.6 percent of audit quality can be explained by the variable Audit Rotation $\left(\mathrm{X}_{1}\right)$, Time Pressure $\left(\mathrm{X}_{2}\right)$, Audit Tenure $\left(\mathrm{X}_{3}\right)$, Auditor Specialization $(\mathrm{Z})$, Interaction $\mathrm{X} 1$ with $\mathrm{Z}\left(\mathrm{X}_{1} \mathrm{Z}\right)$, Interaction of $\mathrm{X}_{2}$ with $\mathrm{Z}\left(\mathrm{X}_{2} \mathrm{Z}\right)$ and Interaction of $\mathrm{X} 3$ with $\mathrm{Z}\left(\mathrm{X}_{3} \mathrm{Z}\right)$. The Standard Error of the Estimate value of 0.416 indicates that the smaller the Standard Error of the Estimate value will make the regression model more precise in predicting the dependent variable.

Table 3

Statistical Test F

\begin{tabular}{llllll}
\hline & $\begin{array}{l}\text { Sum of } \\
\text { Squares }\end{array}$ & df & $\begin{array}{l}\text { Mean } \\
\text { Squares }\end{array}$ & F & Sig \\
\hline 1. Regression & 30.442 & 7 & 4.349 & 25.146 & $.000^{\mathrm{a}}$ \\
$\quad$ Resiual & 68.659 & 397 & .173 & & \\
Total & 99.101 & 404 & & & \\
\hline Source: processed data, 2019 & & & &
\end{tabular}

Source: processed data, 2019

The $\mathrm{F}$ test in table 3 shows the calculated $\mathrm{F}$ value in this research model is 25,146 with a significant level of 0,000 . Significant values below 0.05 indicate that the regression model can be used to predict audit quality. The statistical test results in Table 3 show the regression coefficient for the auditor rotation variable of -0.035 with a significance value of 0.656 which is greater than 0.05 . These results indicate that auditor rotation does not affect audit quality in manufacturing companies listed on the Indonesia Stock Exchange in 2014 - 2018, so the first hypothesis was rejected. The regression coefficient for the time pressure variable is -0.002 with a significance value of 0.042 which is smaller than 0.05 . These results indicate that time pressure influences audit quality on manufacturing companies listed on the Indonesia Stock Exchange in 2014 - 2018 so that the second hypothesis can be accepted. The regression coefficient for the tenure audit variable is 0.066 with a significance value of 0.002 which is smaller than 0.05 . These results indicate that audit tenure affects audit quality on manufacturing companies listed on the Indonesia Stock Exchange in 2014 - 2018 so that the third hypothesis can be accepted.

The regression coefficient for the auditor specialization variable is 0.518 with a significance value of 0.168 which is greater than 0.05 . This shows that auditor specialization does not affect audit quality in manufacturing companies listed on the Indonesia Stock Exchange in 2014 - 2018, so the fourth hypothesis is rejected. The regression coefficient for the interaction variable $X_{1} . Z$ is -0.270 and the significance value is 0.173 which is greater than 0.05 . While the regression coefficient of the auditor rotation variable is -0.035 with a significance value of 0.656 which is greater than 0.05 . Then it shows the relationship is not direct or opposite because it has different coefficient values. The auditor specialization is not a moderating variable the effect of auditor rotation on audit quality, so the fifth hypothesis is rejected.

The regression coefficient for the interaction variable $\mathrm{X}_{2} . \mathrm{Z}$ is 0.003 with a significance value of 0.572 which is greater than 0.05 . While the regression coefficient for the time pressure variable is -0.002 with a significance value of 0.042 which is smaller than 0.05 . Then it shows the relationship is not direct or opposite because it has different coefficient values. The auditor specialization is not a moderating variable the influence of time pressure on audit quality, so the sixth hypothesis is rejected. The regression coefficient for the interaction variable $\mathrm{X}_{3} . \mathrm{Z}$ is -0.075 with a significance value of 0.025 which is smaller than 0.05 . While the regression coefficient for the tenure audit variable is 
0.066 with a significance value of 0.002 which is smaller than 0.05 . Then it shows a direct relationship because it has a positive coefficient. The auditor specialization is the moderating variable of the effect of audit tenure on audit quality so that the seventh hypothesis can be accepted.

\section{Conclusion}

a) Auditor rotation does not affect audit quality in manufacturing companies listed on the Indonesia Stock Exchange in 2014 - 2018, so the first hypothesis is rejected.

b) Time pressure affects the audit quality of manufacturing companies listed on the Indonesia Stock Exchange in 2014 - 2018 so that the second hypothesis can be accepted.

c) Audit tenure affects audit quality on manufacturing companies listed on the Indonesia Stock Exchange in 2014 - 2018 so that the third hypothesis can be accepted.

d) The specialization of auditors does not affect audit quality in manufacturing companies listed on the Indonesia Stock Exchange in 2014 - 2018, so the fourth hypothesis is rejected.

e) Specialization of auditors is not able to strengthen or weaken the effect of auditor rotation on audit quality, so the fifth hypothesis is rejected.

f) Specialization of auditors is not able to strengthen or weaken the influence of time pressure on audit quality, so the sixth hypothesis is rejected.

g) The auditor's specialization strengthens the effect of audit tenure on audit quality so that the seventh hypothesis can be accepted.

\section{Suggestion}

For further research, it is recommended to add other independent variables related to agency theory, such as audit fees, or use other research objects, besides manufacturing companies, such as mining, real estate, and others.

\section{Limitations}

Limitations in this study are the measurement of audit quality variables using big four and non-big four.

\section{Conflict of interest statement}

The authors declared that they have no competing interests.

\section{Statement of authorship}

The authors have a responsibility for the conception and design of the study. The author(s) have approved the final article.

Acknowledgments

We are grateful to two anonymous reviewers for their valuable comments on the earlier version of this paper.

Kirana, I. G. A. M. I., \& Ramantha, I. W. (2020). The effect of auditor rotation, time pressure, and audit tenure on audit quality with auditor specialization as moderation variable. International Research Journal of Management, IT and Social Sciences, 7(3), 126-136. https://doi.org/10.21744/irjmis.v7n3.931 


\section{References}

Andriani, N., \& Nursiam, N. (2018). Pengaruh Fee Audit, Audit Tenure, Rotasi Audit Dan Reputasi Auditor Terhadap Kualitas Audit (Studi Empiris Pada Perusahaan Manufaktur yang Terdaftar di Bursa Efek Indonesia Tahun 2013 2015). Riset Akuntansi dan Keuangan Indonesia, 3(1), 29-39. https://doi.org/10.23917/reaksi.v3i1.5559

Ardani, S. V. (2017). Pengaruh Tenure Audit, Rotasi Audit, Audit Fee terhadap Kualitas Audit dengan Komite Audit Sebagai Variabel Moderasi (Studi Pada Perusahaan Sektor Keuangan yang Terdaftar di Bei Tahun 2010 2014). Jurnal Akuntansi (Media Riset Akuntansi \& Keuangan), 6(1), 1-12.

Arens, A. A., Elder, R. J., \& Mark, B. (2012). Auditing and assurance services: an integrated approach. Boston: Prentice Hall.

Basuki, B., \& Mahardani, K. Y. (2006). Pengaruh tekanan anggaran waktu terhadap perilaku disfungsional auditor dan kualitas audit pada kantor akuntan publik di Surabaya. Jurnal Manajemen, Akuntansi \& Sistem Informasi, 6(2), 203-223.

Bhaskar, L. S., Krishnan, G. V., \& Yu, W. (2017). Debt covenant violations, firm financial distress, and auditor actions. Contemporary accounting research, 34(1), 186-215. https://doi.org/10.1111/1911-3846.12241

Chi, W., Huang, H., Liao, Y., \& Xie, H. (2009). Mandatory audit partner rotation, audit quality, and market perception: Evidence from Taiwan. Contemporary Accounting Research, 26(2), 359-391. https://doi.org/10.1506/car.26.2.2

Church, B. K., \& Zhang, P. (2006). A model of mandatory auditor rotation. In CAAA 2006 Annual Conference Paper (pp. 07-08). https://dx.doi.org/10.2139/ssrn.874884

Crabtree, A. D., Brandon, D. M., \& Maher, J. J. (2006). The impact of auditor tenure on initial bond ratings. Advances in Accounting, 22, 97-121. https://doi.org/10.1016/S0882-6110(06)22005-4

Deil, S. A. F. (2014). Enron Skandal Besar Perusahaan Energi Yang Cekik Investor.

Djamil, N. (2003). Faktor-Faktor yang mempengaruhi kualitas audit pada sektor publik dan beberapa karakteristik untuk meningkatkannya. Jurnal Akuntansi. STIE Nasional Banjarmasin.

Elder, R. J., Lowensohn, S., \& Reck, J. L. (2015). Audit firm rotation, auditor specialization, and audit quality in the municipal audit context. Journal of Government \& Nonprofit Accounting, 4(1), 73-100. https://doi.org/10.2308/ogna-51188

Firth, M., Rui, O. M., \& Wu, X. (2012). How do various forms of auditor rotation affect audit quality? Evidence from China. The International Journal of Accounting, 47(1), 109-138. https://doi.org/10.1016/j.intacc.2011.12.006

Gietzmann, M. B., \& Sen, P. K. (2002). Improving auditor independence through selective mandatory rotation. International Journal of Auditing, 6(2), 183-210. https://doi.org/10.1111/j.1099-1123.2002.tb00012.x

Gul, F. A., Fung, S. Y. K., \& Jaggi, B. (2009). Earnings quality: Some evidence on the role of auditor tenure and auditors' industry expertise. Journal of accounting and Economics, 47(3), $265-287$. https://doi.org/10.1016/j.jacceco.2009.03.001

Hamid, A. (2013). Pengaruh Tenur KAP Dan Ukuran KAP Terhadap Kualitas Audit (Studi Empiris pada Perusahaan Manufaktur yang Terdaftar di BEI). Jurnal Akuntansi, 1(1).

Herusetya, A. (2009). Pengaruh ukuran auditor dan spesialisasi auditor terhadap kualitas laba. Jurnal Akuntansi dan Keuangan Indonesia, 6(1), 46-70. http://dx.doi.org/10.21002/jaki.2009.03

Indriani, R., \& Kusumaputra, A. D. (2017). Kualitas Laba: Implikasi dari Pengaruh Tenure Terhadap Kualitas Audit. EMabis: Jurnal Ekonomi Manajemen dan Bisnis, 17(1), 61-76. https://doi.org/10.29103/e-mabis.v17i1.51

Ishak, F. A. P., Perdana, H. D., \& Widjajanto, A. (2015). Pengaruh Rotasi Audit, Workload, dan Spesialisasi Terhadap Kualitas Audit Pada Perusahaan Manufaktur Yang Terdaftar Di Bursa Efek Indonesia Pada Tahun 20092013. Jurnal Organisasi dan Manajemen, 11(2), 183-194.

Junaidi, J., Hartono, J., Suwardi, E., Miharjo, S., \& Hartadi, B. (2016). Does auditor rotation increase auditor independence?. Gadjah Mada International Journal of Business, 18(3), 315-336. https://doi.org/10.22146/gamaijb.16988

Kesuma, I. B. G. P. W., \& Dwirandra, A. (2019). Professional commitments and pressure of obedience in mediating on the effect of time budget pressure in quality audits. International Research Journal of Engineering, IT \& Scientific Research, 5(1), 27-38. https://doi.org/10.21744/irjeis.v5n1.587

Kurniati, R. (2018). Peran Spesialisasi Industri Auditor Sebagai Pemoderasi Atas Pengaruh Audit Tenure Dan Reputasi Kantor Akuntan Publik Pada Kualitas Audit. Jurnal Ilmiah Professional Indonesia, 2(2), 53-68.

Kurniawansyah, D. (2017). Pengaruh Audit Tenure, Ukuran Auditor, Spesialisasi Audit dan Audit Capacity Stress Terhadap Manajemen Laba (Studi Empiris pada Perusahaan Manufaktur yang listed di BEI tahun 20102015). Jurnal Riset Akuntansi Dan Bisnis Airlangga, 1(1). http://dx.doi.org/10.31093/jraba.v1i1.4 
Lambert, T. A., Jones, K. L., Brazel, J. F., \& Showalter, D. S. (2017). Audit time pressure and earnings quality: An examination of accelerated filings. Accounting, Organizations and Society, 58, 50-66. https://doi.org/10.1016/j.aos.2017.03.003

Lee, D., \& Sukartha, I. M. (2017). Fee Audit sebagai Pemoderasi Pengaruh Auditor Switching dan Audit Temure terhadap Kualitas Audit. E-Jurnal Akuntansi Universitas Udayana, ISSN, 2302-8556.

Lennox, C. (2005). Audit quality and executive officers' affiliations with CPA firms. Journal of accounting and economics, 39(2), 201-231. https://doi.org/10.1016/j.jacceco.2003.12.002

Lestari, N., \& Nedya, S. (2019). The effect of audit quality on tax avoidance. In International Conference On Applied Science and Technology 2019-Social Sciences Track (iCASTSS 2019). Atlantis Press. https://dx.doi.org/10.2991/icastss-19.2019.69

Lowensohn, S., Johnson, L. E., Elder, R. J., \& Davies, S. P. (2007). Auditor specialization, perceived audit quality, and audit fees in the local government audit market. Journal of Accounting and Public Policy, $26(6), 705-732$. https://doi.org/10.1016/j.jaccpubpol.2007.10.004

Lowensohn, S., Johnson, L. E., Elder, R. J., \& Davies, S. P. (2007). Auditor specialization, perceived audit quality, and audit fees in the local government audit market. Journal of Accounting and Public Policy, 26(6), 705-732. https://doi.org/10.1016/j.jaccpubpol.2007.10.004

Maharani, A. P. (2014). Pengaruh Audit Tenure, Audit Fee, Rotasi Audit dan Spesialisasi Auditor Terhadap Kualitas Audit. Jurnal Ekonomi dan Keuangan. Fakultas Ekonomi dan Bisnis. Universitas Muhamadiyah Surakarta.

Nirmala, M. R. V., \& Latrini, M. Y. (2017). Pengaruh Keahlian, Tekanan Ketaatan, Tekanan Waktu Terhadap Kualitas Audit Judgment Dengan Kompleksitas Tugas Sebagai Pemoderasi. E-Jurnal Akuntansi, 683-711.

Nizar, A. A. (2017). Pengaruh Rotasi, Reputasi dan Spesialisasi Auditor terhadap Kualitas Audit (Studi Empiris pada Perusahaan Manufaktur yang Listed di BEI). Kompartemen: Jurnal Ilmiah Akuntansi, 15(2). http://dx.doi.org/10.30595/kompartemen.v15i2.1877

Nugrahanti, Y., \& Darsono, D. (2014). Pengaruh Audit Tenure, Spesialisasi Kantor Akuntan Publik dan Ukuran Perusahaan Terhadap Kualitas Audit (Studi Empiris Pada Perusahaan Manufaktur Yang Terdaftar Di Bursa Efek Indonesia Tahun 2010-2012) (Doctoral dissertation, Fakultas Ekonomika dan Bisnis).

Nuratama, I. P. (2011). Pengaruh Tenur dan Reputasi Kantor Akuntan Publik pada Kualitas Audit dengan Komite Audit sebagai Variabel Moderasi. Universitas Udayana.

Pieters, R., \& Warlop, L. (1999). Visual attention during brand choice: The impact of time pressure and task motivation. International Journal of research in Marketing, 16(1), 1-16. https://doi.org/10.1016/S01678116(98)00022-6

Rahadianto, N. A. (2012). Analisis pengaruh auditor spesialisasi industri, dewan komisaris, komite audit, dan penerapan PSAK 50/55 (revisi 2006) terhadap audit delay pada industri perbankan= Analyzing effect of the auditor specialization industry, board of commissioners, the audit committee, and application of PSAK 50/55 (revised 2006) on audit delay in banking industry.

Rahmina, L. Y., \& Agoes, S. (2014). Influence of auditor independence, audit tenure, and audit fee on audit quality of members of capital market accountant forum in Indonesia. Procedia-Social and Behavioral Sciences, 164, $324-$ 331. http://dx.doi.org/10.1016/j.sbspro.2014.11.083

Rosnidah, I. (2011). Analisis Dampak Motivasi Dan Profesionalisme Terhadap Kualitas Audit Aparat Inspektorat Dalam Pengawasan Keuangan Daerah (Studi Empiris Pada Pemerintah kabupaten Cirebon). PEKBIS (Jurnal Pendidikan Ekonomi Dan Bisnis), 3(02).

Senjaya, K., \& Suprasto, B. (2016). Tingkat Spesialisasi Industri Auditor Sebagai Pemoderasi Pengaruh Ukuran Perusahaan Pada Audit Delay. E-Jurnal Akuntansi, 2013-2040.

Sinaga, D. M., \& Ghozali, I. (2012). Analisis pengaruh audit tenure, ukuran KAP dan ukuran perusahaan klien terhadap kualitas audit (Doctoral dissertation, Fakultas Ekonomika dan Bisnis).

Sumarwoto, S. (2006). Pengaruh Kebijakan Rotasi KAP Terhadap Kualitas Laporan Keuangan (Doctoral dissertation, program Pascasarjana Universitas Diponegoro).

Suryo, M. (2017). Pengaruh time budget pressure dan risiko audit terhadap kualitas audit (survey pada auditor di Kantor Akuntan Publik di Bandung). Jurnal Riset Akuntansi dan Keuangan, 5(1), 1325-1336. https://doi.org/10.17509/jrak.v5i1.6757

Sweeney, B., \& Pierce, B. (2004). Management control in audit firms. Accounting, Auditing \& Accountability Journal. https://doi.org/10.1108/09513570410567818

Tjun, L. T., Marpaung, E. I., \& Setiawan, S. (2012). Pengaruh kompetensi dan independensi auditor terhadap kualitas audit. Jurnal akuntansi, 4(1), 33-56. https://doi.org/10.28932/jam.v4i1.353

Kirana, I. G. A. M. I., \& Ramantha, I. W. (2020). The effect of auditor rotation, time pressure, and audit tenure on audit quality with auditor specialization as moderation variable. International Research Journal of Management, IT and Social Sciences, 7(3), 126-136. https://doi.org/10.21744/irjmis.v7n3.931 
Wang, K. J., \& Tuttle, B. M. (2009). The impact of auditor rotation on auditor-client negotiation. Accounting, Organizations and Society, 34(2), 222-243. https://doi.org/10.1016/j.aos.2008.06.003

Yahya, A. (2015). Pengaruh Audit Tenure, Rotasi Auditor, Ukuran KAP Dan Independensi Auditor Terhadap Kualitas Audit dengan Fee Audit Sebagai Variabel Moderasi Pada Perusahaan Manufaktur Yang Terdaftar Di BEI (20122015) (Doctoral dissertation, Tesis. Yogyakarta: FEB UMY). 